\title{
Batidas e notas sobre turismo e modos de viver e festejar música eletrônica*
}

Beats and Notes on Tourism and Ways of Living and Celebrating Electronic Music

\section{Cássio Lopes da Cruz Novo ${ }^{1}$}

* Recebido em: 18.01.2020. Aprovado em: 23.02.2020

1 Professor de Geografia e Atualidades. Possui Doutorado e Mestrado em Geografia Humana pelo Programa de Pós- Graduação em Geografia - UERJ. Foi Bolsista Doutorado Nota 10 (FAPERJ). Pesquisa e atua no campo da Geografia Humana, com ênfase nas abordagens humanista e cultural do espaço geográfico, em temas como: Carnaval, Festivais de Música Eletrônica, Festivais, Festas Espacialidade; Cultura e Natureza; Meio Ambiente, Sustentailidade e Modos de Vida no Espaco; Geografia e Religiro. Vida Possui trajetória científica atrelada à dimensão cultural das dinâmicas festivas e religiosas no espaço geográfico e na interpretação dos sentidos e significados de ações vividas no cotidiano em relação aos indivíduos e grupos sociais envolvidos com os fenômenos. - E-mail: cassiolcnovo@gmail.com

Resumo: o presente ensaio, derivado de pesquisas empreendidas sobre os modos de festejar música eletrônica na contemporaneidade, investe em possíveis aproximações entre atividades, fluxos e estudos relacionando a ciência geográfica, o turismo e modos de viver festejar música eletrônica na contemporaneidade. Procuramos identificar desafios e possibilidades de articulação entre os campos acima indicados a partir das dinâmicas espaciais ocorrentes em clubes, eventos e festivais de música eletrônica em lugares específicos. As ideias, reflexões e sugestões de caminhos aqui expressos se fundamentam em pesquisa bibliográfica no campo da geografia humanista cultural, da antropologia cultural e do turismo. E almejam articular diálogos e promover confluências entre os campos da geografia e do turismo no contexto da Era da Experiência e com maior atenção aos modos como integrantes de sociedades de fim de semana escolhem se deslocar pelo espaço geográfico e significar suas mobilidades.

Palavras-chave: Turismo. Era da Experiência. Festivais de Música Eletrônica. Turismo Experiencial. Sociedades de Fim de Semana.
Abstract: derived from research undertaken on the ways of celebrating electronic music in contemporary times this essay invest in possible approximations between activities, spatial flows and studies relating geographic science, tourism and ways of living and celebrating electronic music in contemporary times. We seek to identify challenges and possibilities of articulation between the fields indicated above based on the spatial dynamics that occur in clubs, events and festivals of electronic music in specific places. The ideas, reflections and suggestions of paths expressed here are based on bibliographic research in the field of cultural humanist geography, cultural anthropology and tourism. And they aim to promote dialogues and confluences between the fields of geography and tourism in the context of the Era of Experience, giving great attention to the ways in which members of weekend societies choose to move around the geographical space and signify their mobility.

Keywords: Tourism. The Experience Era. Electronic Music Festivals. Experiential Tourism. Weekend Societies. 
A magnitude de sensações e experiências vividas relativas ao festejar música eletrônica na atualidade oportuniza repensarmos uma série de fluxos e atravessamentos pelos quais a presença de cada participante no lugar festivo (FERREIRA, 2002) se torna possível e memorável. Para estar na festa é necessário definir direções a seguir, empreender deslocamentos pelo espaço geográfico e superar distâncias. Entretanto, para membros de communitas festivas, especialmente indivíduos integrantes de sociedades de fim de semana (ST. JOHN, 2017), a presença de seus corpos no lugar festivo (FERRREIRA, 2002) constitui parte de extensa coletânea de ações e significações que esses deslocamentos requerem e possuem quando são efetivados no espaço. Neste trabalho, assumimos que os sentidos e significados dos movimentos dos integrantes de neotribos contemporâneas (MAFFESOLI, 2010) revelam geografias do seu mundo vivido. E, concomitantemente, apresentam-se como fenômenos a serem estudados geograficamente.

O conjunto de ações realizado por sujeitos determinados a se deslocar de uma localidade a outras do espaço geográfico, acrescido pelas dinâmicas existentes no transcurso de suas mobilidades, constitui vasto repertório de práticas humanas as quais vêm sendo, ao longo do tempo, conhecidas, realizadas e estudadas como turismo. De acordo com Flores e Cáceres (2019) a diversidade das modalidades turísticas se amplia, consideravelmente, nas últimas décadas. Dentre um universo tão amplo, os autores apontam o crescimento de uma vertente especialmente voltada para o "turismo de nicho".

Sinalizamos, a partir desse ponto, possíveis confluências entre maneiras de viver e festejar música eletrônica em relação às transformações em curso nos modos de se deslocar para (re)conhecer espaços e lugares. Por esses caminhos, procuramos refletir sobre como o desejo por festejar pode ser vivido - e especialmente qualificado como experiência memorável e luminosa - por intermédio dessas novas possibilidades de pensar e executar ações turísticas. Com isso, entendemos a contribuição dos referidos autores como sinalizações a serem seguidas por quem almeja perceber e interpretar como os fluxos turísticos podem se constituir em contextos espaciais e temporais para a consumação de experiências festivas e de atividades turísticas a elas relacionadas.

As linhas a seguir procuram identificar algumas dessas possibilidades. Assumindo um caráter ensaístico, o texto almeja refletir sobre alguns dos sentidos e significados possíveis para os deslocamentos pelo espaço em busca de experiências festivas para indivíduos e grupos culturais direta e indiretamente implicados com essas dinâmicas especialmente qualificadas, consideradas entre as pausas e movências daqueles que as vivenciam. Para além da mobilidade dos corpos pelo espaço geográfico, intencionamos, ainda em acordo com os estudos de Flores e Cáceres (2019, p. 1), sugerir que "a busca por experiências 'alternativas' parece ocupar lugares e sítios os quais, anteriormente, se sustentavam através de formas mais 
${ }^{2}$ As cidades, de acordo com o GaWc, são classificadas em razão da interconectividade e da capacidade de influência que apresentam a partir dos fixos e fluxos a elas relacion dos Disponível em: https://www.lboro.ac.uk/gawc/gawcworl ds.html. Acesso em 25/09/2020. convencionais de exploração turística". E que, atualmente, estão sendo transformados pela diversidade de sujeitos dedicados a experienciar espaços, lugares e eventos geográficos festivos no âmbito da Era da Experiência (PINE e GILMORE, 1998).

Os enlaces de geografias do cotidiano revelam trajetórias espaciais. Assim, os deslocamentos de turistas pelo espaço geográfico semiografam os caminhos que empreendem em busca de seus desejos, interesses ou sonhos. Ao se movimentarem, materializam percursos que foram, anteriormente, imaginados como roteiros. Nesses casos, os roteiros para festejar expressam sonhos, devaneios, desejos e as imaginações geográficas dos indivíduos que anseiam viver a experiência festiva corporificada em específicos lugares de maneira a torná-la especialmente qualificada e luminosa (NOVO, 2019).

Ainda que a prática turística e a experiência festiva sejam reconhecidamente constituídas por elementos subjetivos, particulares e nem sempre extensivos a outros sujeitos envolvidos com as ações em curso, é importante reconhecer a existência de lugares simbólicos capazes de atrair indivíduos e grupos movidos por interesses e/ou valores em comum. Alguns fixos no espaço geográfico tornam-se, a partir das dinâmicas espaciais a eles vinculadas no decurso do tempo, lugares simbólicos para determinadas pessoas e seus grupos culturais.

Partamos, para reflexões iniciais, para a pluralidade de gêneros e vertentes da música eletrônica de pista. Em termos culturais, algumas dessas vertentes, no contexto espacial onde são produzidas/reproduzidas, alcançam o status de patrimônio cultural intangível. O gênero techno, por exemplo, passou a ser considerado patrimônio cultural intangível da UNESCO desde o ano de 2017. É interessante apontar que essa valorização efetivou-se por intermédio dos governantes da cidade de Zurique, na Suíça. Em suma, promoveram o gênero musical como reconhecimento pela contribuição que o mesmo vem oferecendo à cidade nos últimos anos. De acordo com a reportagem da revista especializada em música eletrônica de pista, o comitê diretivo da UNESCO apontou o seguinte conjunto de elementos para nossa reflexão: "o desenvolvimento da cultura techno em Zurique, com a Street Parade e uma cena marcante de clubes, empresta à cidade uma reputação jovem, aberta, hedonista e internacional" (DJ MAG BRASIL, 2017).

A passagem acima apresenta um espaço em transformação em termos das dinâmicas espaciais, sociais e culturais a ele associadas e nele realizadas. Também sugere a atenção do poder público de uma cidade global "alfa" 2 para engendrar e executar estratégias de atração de fluxos variados para si, especialmente em um período iniciado no último quartel do século passado em que a "guerra dos lugares" se desenvolve com ênfase na valorização e promoção de experiências de consumo de luxo (LIPOVETSKY, 1998) em si e, mais recentemente, com o turismo de nichos segmentados (FLORES e CÁCERES, 2019). 
Diante do contexto acima apresentado, é importante questionar: a valorização de elementos da cultura de um lugar, especialmente significativos para um determinado grupo cultural, é capaz de impactar a atividade turística? No caso do techno e sua relação com a Zurique, é necessário avançar no entendimento de que a sua difusão espacial requer artefatos e equipamentos urbanos e culturais condizentes com o perfil dos turistas e participantes dos eventos geográficos festivos a eles relacionados.

O exemplo acima, entretanto, emerge como um ponto noda de extensa rede de lugares, eventos, ações e simbolismos associados ao festejar música eletrônica e aos renovados modos de promover e viver atividades turísticas. Ao considerar o protagonismo dos indivíduos e suas ações no espaço geográfico para qualificar vivências e significar experiências vividas no âmbito de hodiernas maneiras de festejar e viajar, o presente ensaio se desdobra em três seções, a saber:

i. Notas sobre modos de viver e festejar música eletrônica contemporaneamente;

ii. Clubes, eventos e festivais de música eletrônica como campo de possibilidades para atos e estudos relacionados à atividade turística;

iii. Notas sobre geografia e turismo no contexto da Era da Experiência em sociedades de fim de semana.

\section{Notas sobre modos de viver e festejar música eletrônica contemporaneamente}

Desde os primórdios, as sociedades humanas criam e refinam variados modos de festejar. Motivados para celebrar e ritualizar encontros com seus deuses, com o sagrado, com o mistério, com elementos da natureza, outros povos e/ou, simplesmente, com outros sujeitos festivos, os indivíduos se mobilizam para atravessar distâncias e viver, em lugares-outros, aventuras extraordinárias (CLAVAL, 1999). Há vasta literatura concernente ao tema festas na qual o ato de festejar pode ser examinado em termos da busca de momentos e sensações capazes de retirar os sujeitos da rotina, da normalidade ou da indiferença e monotonia de seus dias e noites corriqueiros

Em seus estudos antropológicos Cavalcanti (1999) sinaliza algumas das mais "tradicionais" abordagens científicas do tema festa. Por uma perspectiva durkheiminiana a festa seria força criadora efetivada pela efervescência social agindo sobre a consciência. Outras possibilidades usualmente consideradas apontam para as festas como eventos ligados ao excesso e à transgressão ou, ainda, interpretados como emergências daquilo que, rotineiramente, é suprimido no convívio regular das sociedades modernas. Abordagens sobre as festas a partir de seus rituais e dos locais privilegiados para a compreensão de sociedades humanas onde e quando vivências festivas e cotidianas se encontram ou evidenciar as 
dimensões cultural, pública e coletiva dos festejos, convivem com pesquisas que se debruçam na sobreposição dos domínios do lúdico, do estético, das tonalidades afetivas e referentes à materialidade e imaterialidade presentes em relação ao festejar.

A imaginação em ação aproxima as pessoas daquilo que desejam alcançar (COSGROVE, 2000). A criatividade humana desenvolve-se de maneira a formular jeitos variados e refinados de buscar satisfazer desejos ou perseguir ilusões (LOWENTHAL, 1982). Dentre as possibilidades criadas e vividas para se conecta com aquilo que não conseguem explicar, muitas culturas concebem, criam e reconfiguram a realização de ritos e práticas que envolvem a reunião de indivíduos ouvindo músicas, dançando, alimentando-se e comemorando. Inúmeras sociedades, ao longo da história conceberam e recriaram maneiras $\mathrm{e}(\mathrm{m})$ tempos específicos para festejar. Fizeram isso, e ainda fazem, para escapar da rotina de uma vida ordinária, retirando da mesmice indivíduos e permitindo que eles nutram suas existências de sentidos, significados e sensações (DUVIGNAUD, 1977; TUAN, 2015).

Em se tratando dessa busca pela aventura, pela quebra da monotonia da vida cotidiana e pela instauração de novas dinâmicas e ações durante determinadas temporalidades, o ato de viajar acompanha - e adensa - as possibilidades e oportunidades de viver experiências festivas como modalidades de escapismo espacial, temporal e existencial (NOVO, 2019). O geógrafo Paul Claval (1999) destaca o potencial de algumas festividades em suspenderem o rigor ou a aplicação das regras habituais de convivência, vigilância e controle social. As festas, entendidas por esta perspectiva, se habilitam a serem vividas como modos de inverter hierarquias, oferecendo-se ao serviço de terapia coletiva para a sociedade (CLAVAL, 1999). Ou, ainda, como meios para promover e conferir sentidos a mobilidades pelo espaço.

Festejar consiste em um conjunto de práticas e dinâmicas eminentemente humanas. $\mathrm{O}$ ato de festejar é inerente a sujeitos que produzem e consomem os eventos geográficos festivos (SILVA, 2013) como complexas experiências espaciais. As interações ocorrem a partir de relações interpessoais, intersubjetivas e em relação com o espaço geográfico onde e quando as festividades ocorrem. Em outras palavras: toda festa - e todo ato de festejar reivindica uma componente espacial na medida em que depende do espaço geográfico para ser realizada e/ou vivida. Inescapavelmente, festas e modos de festejar refletem o "espírito do tempo" em que estão sendo vividas, isto é, o zeitgeist de uma sociedade ou de uma geração (SOARES, 2014).

A partir da segunda metade do século passado, inúmeras transformações desencadeadas a partir da revolução do meio técnicocientífico-informacional (SANTOS, 1987) ensejaram modos de festejar mais plurais, diversificados e em ritmo acelerado e constante de transformações (CLAVAL, 2010; ST. JOHN, 2010). A inserção de equipamentos eletrônicos capazes de modular as ondas sonoras e distorcer sinteticamente suas frequências passam a configurar novas 
sonoridades, as quais, inexoravelmente, oportunizam novas sociabilidades e modos de festejar. Nas últimas décadas, o conjunto dessas transformações vincula-se às culturas criadas e dinamizadas a partir de indivíduos reunidos para dançar e festejar música eletrônica de pista (SOARES, 2014) em cenas locais e no âmbito de culturas globalizadas (ST. JOHN, 2017)

Alternando entre as escalas local e global, e agindo como portadores e dinamizadores de elementos e símbolos de suas culturas, esses sujeitos constituem neotribos contemporâneas (MAFESOLLI, 2010) e integram sociedades de fim de semana (ST JOHN, 2017), cujo propósito consiste em viver intensamente ritos e atos associados ao festejar música eletrônica em lugares especialmente projetados para tornar essas experiências ainda mais intensas e memoráveis (ST. JOHN, 2014; NOVO, 2019).

Unidos por uma comunidade psíquica e se reconhecendo entre comunidades específicas de ravers, festivaleiros e/ou entusiastas das culturas associadas à música eletrônica (ST. JOHN, 2010), indivíduos de diferentes nacionalidades vivem ordinária localmente suas vidas de maneira a projetar possibilidades de participação e interação nessas culturas cada vez mais globalizadas.

Ainda que as redes sociais e a virtualização de eventos e experiências festivas seja uma realidade - acelerada e intensificada no contexto dos Tempos Pandêmicos (HAESBAERT, 2020) atuais o desejo por estar em um lugar simbólico e/ou material, um lugar fisicamente preparado para receber os corpos de sujeitos para festejar, se mantém. E participa, muitas vezes como protagonista, das escolhas individuais desses sujeitos. Nesses casos, assume-se que as festas e a disposição para viajar e viver festejando adquirem caráter existencial para indivíduos e grupos culturais distribuídos em diferentes áreas do planeta.

Atualmente os processos de desenvolvimento do capitalismo sugerem aberturas amplificadas para a promoção de eventos almejando impactar positivamente os consumidores em escala global a partir de estratégias locais de ativação de fluxos. Acionando as ideias de Corrêa (2007; 2018), apontamos a intencionalidade com que determinados espaços geográficos - como clubes noturnos, festivais, paradas musicais e eventos geográficos festivos em geral são projetados para serem, por específicos grupos culturais, transformados em lugares de entretenimento e lazer. Nesses casos, as ações de afetar e impactar positivamente as experiências de outros indivíduos constituem refinada estratégia do capitalismo contemporâneo e, como tal, podem ser interpretadas como formas simbólicas espaciais (CORRÊA, 2018) criadas, vividas e significadas no contexto de fruição de lazer e entretenimento de luxo (LIPOVETSKY, 1998) no âmbito da Era da Experiência (PINE e GILMORE, 1998)

Pelas ideias expostas acima, as festas ocorrentes no espaço geográfico permitem múltiplas interpretações em relação aos sentidos e significados que apresentam para o complexo e diversificado conjunto de sujeitos com elas envolvidos. Tomadas 
como formas simbólicas espaciais clubes, festivais e eventos geográficos festivos apresentam elementos materiais e imateriais os quais, em conjunto com as cidades e localidades que os sediam, revestem-se de significativa importância para os participantes de suas edições. Amalgamados, ainda que no decurso das temporalidades associadas ao festejar, festas, festivais, participantes e os lugares onde esses encontros festivos são oportunizados constroem um complexo sistema de significados, narrativas e elementos que são atrativos para outras festas, festivais, participantes, marcas, cidades e demais envolvidos com as transformações do espaço e das culturas através de experiências festivas.

\section{Clubes, eventos e festividades de música eletrônica como campo de possibilidades para estudos relacionados à atividade turística}

Existem, atualmente, inúmeras vertentes de música eletrônica. Cada qual atrai e influencia determinados grupos afeitos ao estilo musical e comportamentos a eles associados. As interações oportunizadas pela reunião de artistas, produtores de eventos e participantes em um local e tempo previamente escolhidos para receber esses encontros enseja, em alguns casos, profunda identificação com um ou mais lugares específicos. Procuramos, nas linhas a seguir, desfiar alguns pensamentos acerca de aproximações e possibilidades de estudos, relacionando atividades turísticas com eventos geográficos festivos e o festejar música eletrônica de pista.

Tomemos, como ponto de partida para nossas reflexões, a cidade estadunidense de Chicago. Durante a década de 1970 apresentava-se como uma das mais importantes cidades industriais do país. E, em suas áreas periféricas, foram gestados processos de criação, desenvolvimento e difusão do gênero house. Em se tratando de modalidades heterodoxas de turismo, eventos geográficos festivos associados aos referidos gêneros, nas cidades a eles vinculadas, podem guiar a elaboração de projetos turísticos heterodoxos. Ou, ao menos, não tão convencionais. Investir em atividades turísticas de nicho para o segmento de amantes ou curiosos pela geo-história de difusão de vertentes da música eletrônica através de clubes e cidades lendárias se oferece como campo de possibilidades para a promoção de mudanças nos imaginários e práticas turísticas do presente como meios de vasculhar o passado em busca de vestígios e sinais dos diferentes modos pelos quais o espaço geográfico era organizado, vivido como palco de disputas e, ainda, como meio onde as diferentes tribos urbanas interagiam a partir dele e com ele.

A promoção de roteiros para interessados nas culturas clubber ou no gênero house, por exemplo, suscitam o desvelar do clube Warehouse transformado em lugar de acolhimento, pertencimento e integração entre negros, gays e latinos na cidade de Chicago (REYNOLDS, 1999). Mais uma vez acionamos a 
3 Modo como são nomeadas (e referenciadas pelos adeptos da cultura eletrônica de pista) as músicas elaboradas por produtores de música eletrônica. contribuição de Flores e Cáceres (2009), por entender que as reflexões aqui expressas apontam para modalidades turísticas heterodoxas e multidimensionais. Isto é, sugerem possibilidades de conhecer pessoas, lugares e suas culturas a partir de experiências e práticas espaciais não convencionais. Nesses casos, certos sítios podem adquirir diferentes sentidos e significados de acordo com os indivíduos e os grupos que para eles se voltam. Inclusive, como no caso aqui em tela, pela impermanência da estrutura física do Warehouse. Mas pelas oportunidades de revisitar seu valor para os adeptos do gênero. Acreditamos, no entanto, que projetos nesse sentido requerem atenção especial para a agenda de simbólicas datas e eventos geográficos festivos especialmente capazes de atrair as atenções e as pessoas para esses sítios históricos.

Enquanto o gênero house mantém os vocais herdados das insinuantes e melódicas trilhas sonoras de clubes lendários como o Warehouse, naquela época, já consolidados na disco music, outro gênero, o Techno, se distancia do ritmo da cidade dos ventos eliminando a vocalização na produção de tracks $^{3}$ repletas de sons enérgicos, metálicos e tecnológicos (CHIAVERINI, 2009). Nesta proposição ensaística, elegemos a cosmopolita Berlim como uma cidade potencialmente capaz de ser tomada enquanto lugar dos enlaces entre modos de viver e festejar música eletrônica e os imaginários, discursos e práticas de atividades turísticas compreendidas como campo intersticial onde se articulam elementos históricos, sociais e dos resultados - em transformação - de paisagens das culturas hegemônicas, residuais ou emergentes (COSGROVE, 2012).

O ajuste na escala de observação da proposição acima ilumina clubes berlinenses como Tresor e Berghain. No sentido em que estamos a conjecturar possibilidades entre modos de festejar e turismo, ambos emergem como formas simbólicas espaciais capazes de evocar o passado em que a cidade, o país - e o mundo encontravam-se divididos entre áreas de influência capitalista e socialista. E entre zonas de luminescência e opacidade para o florescer ou fenecer de atividades relacionadas ao lazer. Atualmente, os referidos clubes atuam como fatores de atração para os amantes dessa vertente reconhecida pelos sons que reproduzem as batidas do maquinário associado às indústrias do século passado. Pessoas do mundo inteiro se encaminham para Berghain, Tresor e demais clubes lendários almejando experiências musicais singulares, a vivência de uma atmosfera única e a oportunidade de conhecer e participar da história em construção de lugares simbólicos para a música eletrônica.

Nos casos dos clubes em tela, é importante destacar que a experiência festiva tende a se tornar ainda mais densa se, aos frequentadores dessas casas noturnas, também estiverem disponíveis opções de imersão na história e geografia da cidade que os hospedam. Algumas empresas e iniciativas de free walking tour, especialmente em cidades globais e turísticas como Berlim, oferecem modalidades tematizadas e plurais de conhecer a cidade. 
${ }^{4}$ Parada é o termo utilizado para se referir ao evento geográfico festivo Parada LGBTY+
Flores e Cáceres (2009) sugerem, para essas renovadas modalidades turísticas, a passagem de uma abordagem excursionista para uma de natureza mais experiencial e imersiva.

Considerando possibilidades heterodoxas de ativação turística, seria possível oferecer aos clubbers passeios organizados para apresentar a cidade em relação aos aspectos materiais e locacionais de sua construção, suas efemérides, arquitetura e transformações paisagísticas? Desdobrar as ações de modo a incorporar expedições especialmente destinadas aos interessados em temas como arte de rua, o Terceiro Reich e o período da Guerra Fria? E tornar essas práticas, tradicionalmente conectadas ao turismo mais convencional, como estratégias de uma ação mais plural em que as temporalidades festivas, para além das horas no interior dos clubes, possam aprofundar e enriquecer a experiência no clube pelas experiências pretéritas (e até mesmo as futuras, que virão a se somar com as anteriores a formação das memórias afetivas desse tempo vivido) de imersão na cidade e nas histórias e de acontecimentos associados à cultura eletrônica de pista?

Noites e dias festejando música eletrônica podem se tornar difíceis de serem contabilizados em ambientes fechados, poucos iluminados e onde artistas e público podem permanecer por até três dias ininterruptos imersos em suas dinâmicas hedonistas. Alternativos ao confinamento em espaços fechados, os eventos ao ar livre também movimentam a cena eletrônica. E, por conseguinte, ensejam movimentações de pessoas pelo espaço geográfico. Paradas de ruas, por exemplo, possuem fator de atração para sujeitos dispostos a militar, somar e/ou festejar causas e valores caros a determinados grupos culturais.

Atraídas pelas manifestações festivas, quer seja no espaço público, quer seja em áreas privadas destinadas a esses eventos, milhares de adeptos de sons, palavras de ordem, fantasias e adereços, além de sonoridades eletronicamente distorcidas, organizam suas agendas, investem seus recursos e se encaminham para os lugares destinados a sediar tais encontros. O exemplo que elencamos enfoca a Street Parade de Zurique. Essa parada, realizada em via pública, já contabilizou mais de um milhão de pessoas reunidas em uma mesma edição. Diante da monumentalidade alcançada pela organização do evento, dispomos-nos a refletir sobre possibilidades de empreender ações e estudos turísticos em relação ao fenômeno.

A maior cidade da Suíça abriga menos da metade daquela expressiva quantidade de pessoas como seus habitantes regulares. A cosmopolita cidade é considerada uma cidade global "alfa", sediando em seu território instituições financeiras e bancárias, organizações e entidades internacionais e supranacionais, assim como centros de pesquisa e desenvolvimento tecnológico e científico. Como consequência direta dessa centralidade os fluxos convergentes à cidade e a partir dela reorganizados e difundidos se enovelam de modo a configurar novas possibilidades de entrecruzamentos. E, inevitavelmente, oportunidades para a ativação de novas dinâmicas espaciais. 
Em 2017, a cidade foi agraciada com o título de maior parada $^{4}$ techno comemorada em vias públicas do mundo. A primeira edição do evento, em 1992, atraiu mil pessoas às ruas que circundam o lago de Zurique. Atualmente o evento reúne mais de um milhão de pessoas, ocasionando impactos positivos e negativos ao lugar. Sua relevância foi validada e legitimada pela UNESCO quando, em 2017, foi declarada patrimônio cultural intangível pela Organização das Nações Unidas para a Educação, a Ciência e a Cultura (DJ MAG BRASIL, 2017). Paradas como a Street Parade de Zurique podem ser entendidas como manifestações festivas habilitadas a fazer emergir à cena pública questionamentos, reivindicações e aspirações de grupos periféricos e/ou marginalizados, historicamente ativos nos enfrentamentos por direitos sociais e políticos.

A monumentalidade adquirida pela referida parada, entretanto, desloca questões e ações do nível local para as escalas nacional e, nesse caso, internacional. Se, por um lado, ilumina essas questões, ensejando o debate e a publicidade das pautas e reivindicações dos grupos ali reunidos, por outro lado a ocorrência desses eventos sugere a transformação do fenômeno inicial em um movimento massificado, de caráter midiático e turistificado Importante elemento de coesão entre pessoas compartilhando ideais, valores, ideologias políticas e gostos musicais semelhantes ou, ao menos, convergentes, a parada de rua de Zurique inscreve-se como destino turístico para sujeitos interessados nessas dinâmicas. Assim como também se apresenta como alternativa para modalidades de turismo cultural, motivado e desenvolvido em torno de ações e pautas com propósito social. Ou, ainda, como opção para interessados em vivências singulares, possuidoras de alcance e repercussão global e, também, para desejosos por oportunidades de experienciar eventos festivos de natureza identitária, militante e/ou reivindicativa.

A Street Parade da maior cidade suíça vem se constituindo, anualmente, como luminoso evento geográfico festivo (SILVA, 2013). Atraindo para si centenas de milhares de turistas, ravers e interessados nas dinâmicas festivas ocorrentes em suas ruas no entorno do lago da cidade. Sujeitos que, uma vez na cidade global, incorporam-se à miríade de fluxos oportunizados por uma pólis especialmente qualificada. E, nas temporalidades anteriores e posteriores ao acontecer festivo que lhes servem de motivação, pretexto e objetivo, espraiam-se e transbordam por áreas além do espelho d'água lagunar, afetando as rotinas espaço-temporais dos habitantes locais, impactando restaurantes, bares e o setor terciário como um todo. Nesses compassos, a parada se oferece a ser investigada como manifestação da cultura no espaço geográfico. E, como tal, é entendida no âmbito da dimensão festiva à qual se vincula, podendo ser interpretada de diferentes modos.

Tomada como forma simbólica espacial móvel (CORRÊA, 2018), a parada, ao ser realizada anualmente, encarna sentidos e significados afirmados e difundidos pelos grupos ali reunidos. O sentido das movimentações, repetido a cada ano, possui a função de 
${ }^{5}$ É importante atentar que neste texto existem duas localidades nomeadas com a mesma nomenclatura: (i) Boom, festival português de trance psicodélico e (ii) Boom, localidade que abriga o festival belga Tomorrowland desde a sua primeira edição. criar e reviver o itinerário simbólico, o qual passa a integrar o repertório de ações espacializadas dos grupos e, com isso, o sentido de lugar para a comunidade é ativado e (re)vivido. Nesses compassos, as memórias afetivas festivas dos seus participantes também podem ser acessadas e impactadas.

De acordo com Corrêa (2018), mesmo os movimentos realizados no espaço que não estejam inscritos no cotidiano possuem, como elemento distintivo, a repetitividade do itinerário. A permanência desses fluxos, organizados no mesmo sentido, ainda que em temporalidades distintas, favorecem a criação dos itinerários simbólicos. Muitos dos quais se oferecem a ser estudados de modo a configurarem programas turísticos especialmente elaborados para sujeitos contemporâneos interessados em modalidades mais experienciais e imersivas de viver suas identidades e valores no espaço geográfico em temporalidades extraordinárias.

Em termos das aproximações entre o turismo e a geografia de eventos geográficos festivos, a parada de rua admite ser interpretada como um fato social total (MAIA, 2010). Isto é, não limitada apenas, à dimensão política, econômica, turística ou existencial. Antes disso, transversal e transversalizante a todas essas, ela pode ser imaginada, vivida, significada e disputada como movimento político em disputa no tempo e no espaço por distintos grupos sociais; como patrimônio cultural intangível, como um ativo do calendário oficial de eventos da cidade; como elemento destacado do setor turístico e, ainda, como experiência significativa para sujeitos mais identificados com os valores e ideologias ali expressos e potencializados pelo espaço-tempo festivo.

Não obstante, convém atentar que um fato social total dessa natureza, e anunciado dessa maneira, no contexto de uma sociedade midiática, hiperconectada e desejosa por experiências singulares para serem vividas e compartilhadas in-loco e on-line, apresenta-se como substancial manifestação da cultura no espaço geográfico. E, desse modo, pode ser direta ou indiretamente aproximada de fluxos e atividades turísticas segmentadas por questões ou afiliações temáticas, identitárias, orientadas por gênero ou, ainda, qualificadas em razão das motivações e propósitos em tela e em seus desdobramentos espaciais.

De modo geral e abrangente, as contemporâneas culturas urbanas vinculadas ao universo da música eletrônica constroem e significam manifestações festivas espacializadas centradas em eventos que variam em forma, escala, localidades, temporalidades e reprodutibilidade. Nesse sentido, a ideia de neotribalismo (MAFFESOLI, 2010) é acionada para interpretar modos pelos quais participantes encontram, nas interações coletivas ocorridas no espaço-tempo festivo, algum tipo de identificação com determinados grupos culturais, sentimentos de pertencimento e/ou algum senso-dosagrado independente de fontes tradicionais como, por exemplo, igreja, estado ou família (ROSENDAHL, 2014; St. JOHN, 2014; NOVO, 2019). 
A fruição de eventos nos quais ocorre a reunião de indivíduos para o gozo coletivo em eventos festivos relacionados à música eletrônica admite mais de uma origem no tempo e no espaço. Em razão do acelerado processo de expansão das atividades de entretenimento e lazer na esteira do fenômeno da globalização (MASSEY, 2000), especialmente em consonância com os refinados modos como a atual fase do capitalismo econômico busca reinventar-se constantemente, muitos encontros para festejar música eletrônica, em que pese a insistência de muitos ao procurar salvaguardar uma espécie de "tradição" periférica, uma vibe underground, tornaram-se eventos geográficos festivos capazes de movimentar cifras de vultoso montante. Muitos desses eventos são organizados no formato de festivais, reunindo centenas de artistas, milhares de participantes e inúmeras atrações em um lugar e tempo previamente determinados.

De modo a ilustrar as ideias aqui apresentadas, é possível apontar megafestivais de música eletrônica como outros campos férteis para estudos e atividades concernentes ao turismo. $\mathrm{O}$ festival belga Tomorrowland e o lusitano Boom ${ }^{5}$, por exemplo, figuram entre alguns dos festivais mais conhecidos em se tratando de eventos globalmente difundidos e nacionalmente relevantes. Em razão da importância e destaque que possuem, oportunizam deslocamentos de milhares de pessoas pelo espaço geográfico. Essas movimentações integram, convergem e ativam fluxos turísticos variados, ativos em temporalidades anteriores e posteriores às edições de cada um desses festivais, impactando toda uma cadeia produtiva relacionada às festas e aos setores ligados ao turismo em especial (SARMENTO, 2007).

Os festivais acima identificados, apesar de suas especificidades, possuem elementos convergentes: oferecem aos participantes, mediante modalidades alternativas de ingresso, a possibilidade de experiências imersivas no espaço e tempo festivos O acampamento, como modalidades de fruição de festivais como esses em tela, resgatam modos pretéritos de festejar. E (re)ativam possibilidades de rompimento com o cotidiano e ordinário fluxo da vida urbana. Nesse sentido, é importante salientar que acampar nesses festivais é uma prática vivida e significada como experiência escapista para sujeitos contemporâneos (NOVO, 2019). Sujeitos que estão habitualmente envolvidos com tarefas laborativas, hiperconectados por intermédio de redes sociais e dependentes de dispositivos móveis. $\mathrm{Na}$ cidade, em geral, experimentam a aceleração do tempo no espaço como necessidade e urgência, não como possibilidade e deleite. (BONDÍA, 2002; MAFFESOLI, 2010).

As atividades turísticas enquanto práticas escapistas contemplativas seguem, sem dúvida, adequadas a um universo considerável de consumidores. Não obstante, procuramos iluminar alternativas capazes de promover a comunhão entre as dinâmicas turísticas e festivas. E o fazemos intencionado a identificar alguns aspectos positivos e outros negativos inerentes ao possível enlace entre os campos. Para tanto é preciso ir além da extensa e rica gama 
de estudos usualmente contemplados por investigações dedicadas à análise de dados referentes sobre: (i) ocupação de leitos; (ii) aumento na circulação de espaços privados e públicos; (iii) impactos positivos nas economias locais; e (iv) os impactos negativos concernentes à vulnerabilização, exploração e indiferença em relação às populações locais, assim como pelo uso de serviços ambientais.

E, complementarmente, investir em um campo ainda em aberto para o desenvolvimento de estudos acerca das imaginações geográficas (LINDÓN e HIERNAUX, 2010), perspectivas experienciais de reduzida duração e ampliada intensidade (FLORES e CÁCERES, 2019), e mecanismos de ativação e significação dos desejos que festivaleiros e turistas interessados em aspectos e elementos das culturas associadas à música eletrônica em geral nutrem por viver experiências e conhecer cidades próximas a esses festivais (ST. JOHN, 2017). Ou seja, aprofundar estudos e abrir novos campos de pesquisas para compreender mais a fundo o que desejam conhecer - e viver - festivaleiros e turistas que estão alternando deslocamentos e pausas em relação aos festivais para os quais se encaminham.

Nos compassos das reflexões oportunizadas acima oferta-se a oportunidade de indagar: de que modo os municípios podem oferecer atrações compatíveis e, talvez, inseridas no fluxo das experiências e temporalidades festivas que orientam os festivaleiros em suas deambulações pelo espaço geográfico? Ou ainda: como tornar experiências vividas em festivais de música eletrônica ainda mais intensas e memoráveis ao promover programações e destinos turísticos para esses indivíduos, compreendendo o complexo conjunto de sensações e sentimentos que ambicionam viver antes e depois dos festivais?

Os questionamentos supramencionados se tornam mais relevantes quando enfocam as lugaridades e espacialidades de festivais e festivaleiros. E, a partir de então, busca-se compreender a perspectiva experiencial do lugar festivo construída e significada em lugares-outros daqueles onde os festivais efetivamente são realizados. Igualmente importante, destacamos que as possíveis convergências entre estudos e projetos turísticos com os modos de festejar música eletrônica requerem entender a existência - e a importância - de temporalidades ampliadas para momentos anteriores ao início oficial dos eventos. Nesses casos, para considerar as imaginações geográficas que atuam na criação dos desejos e sentidos de lugar festivo. E, também, aquelas ulteriores ao encerramento oficial dos mesmos, de maneira a incorporar necessidades físicas, psicológicas e existenciais de seus participantes em função das dinâmicas vividas intensamente na transcorrência dos dias e noites dedicados à efervescência festiva.

Os grandes festivais, significados como "sonho de consumo" ou "desejo de uma vida" por festivaleiros, ravers e interessados na cultura de música eletrônica, integram redes sazonais de produção e fruição de festas conquanto são ativados na categoria de festivais regionais realizados em dezenas de países (ST. JOHN 
2010). Muitos desses eventos se orientam por padrões culturais em constante negociação e disputam a atenção de pessoas, marcas e cidades de modo a viabilizarem suas edições presenciais. A experiência imersiva em festivais desta natureza adquire significados resultantes de entrelaçamentos musicais e estilísticos, suficientemente poderosos para atrair amantes da cena eletrônica, assim como curiosos por conhecer as dinâmicas festivas cada vez mais difundidas através de elaborados produtos midiáticos - teaser trailers e aftermovies - que são apresentados para a comunidade reunida para festejar (NOVO, 2019).

No tocante às possibilidades de aproximações entre essas realizações e seus estudos com atividades e pesquisas que focalizam o turismo, é interessante atentar que, recorrentemente, as cidades escolhidas para sediar tais eventos são apresentadas como protagonistas do evento que sediam. Ou seja, é possível examinar de que modo cidades qualificam os festivais que hospedam e em que medida os festivais atuam no sentido de qualificar as cidades que os recebem. Especialmente na complexidade e competitividade do mundo atual, de extrema rivalidade pela atração de fluxos globais variados para locais específicos, estudos dessa natureza podem servir de referencial teórico, além de gerar resultados potencialmente utilizáveis, no que se convenciona denominar como guerra entre lugares nos domínios da ciência geográfica.

Maneiras refinadas de participar desses fluxos continuam sendo (re)inventadas e praticadas. Entusiastas, adeptos e fãs de determinados artistas ou vertentes da cena eletrônica organizam suas vidas e trabalho de modo a se disponibilizarem para participar presencialmente desses eventos geográficos festivos. Ou, ainda, interagirem não presencialmente, de maneira síncrona e/ou assíncrona, com a comunidade, tornando-se, segundo St. John (2010), integrantes de comunidades psíquicas. Se, por um lado, inúmeras oportunidades de conexão e interatividade vêm sendo ampliadas no âmbito da hiperconectividade contemporânea, por outro lado, os desejos por estar presente e participar presencialmente desses eventos permanecem ativos como motivadores de deslocamentos espaciais para os participantes. Assim sendo, se apresentam como campo de possibilidades para estudos e ações no campo do turismo em relação e em proposição dialógica com os domínios da economia comportamental, da neurociência e de uma geografia psicológica afeita aos modos como os indivíduos qualificam suas experiências espaciais.

Mais um profícuo campo de possibilidades disponível para semeadura pesquisativa e intelectual envolve identificar e interpretar maneiras variadas de significar a experiência campista em festivais de música eletrônica. E procurar revelar sentidos de ser - portanto ontológicos - de sujeitos afetados por essa modalidade de habitar festivais. Para festivaleiros adeptos do acampamento em festivais, essa modalidade é vivida como pausa no fluxo contínuo de suas atribuições urbanas (CHIAVERINI, 2009; SOARES, 2014). E, vivida como escape, adquire tonalidades e conotações afetivas 
responsáveis por atribuições de sentido existencial para os envolvidos com a sua prática no contexto de fruição dos festivais. A barraca posicionada sobre uma determinada parcela do solo oportuniza a construção do sentido de lugar festivo (RELPH, 2012 NOVO, 2019). E, nessas condições, condiciona lugar e tempo para que bombardeios de estímulos sensoriais possam ser recebidos e consequentemente processados, objetivando a organizar mentalmente alguns dos significados relativos ao arrebatamento das dinâmicas festivas, nem sempre possíveis de serem interpretadas e significadas onde são vividas intensamente.

A modalidade campista, vivida como pausa no lugar, corresponde a estratégias organizativas-criativas pelas quais participantes (re)criam e (re)negociam os significados de estar ali, combinando-os de modo a fazerem sentido para si e para os demais partícipes da sociedade de fim de semana que integram. Como é possível que essas pausas sejam atravessadas pelas possibilidades oferecidas por modalidades de turismo pensadas e executadas de maneira a tornar ainda mais relevantes essas indagações e buscas existenciais? Como a atividade turística pode se comprometer com a provocação ou significação de eventos, sensações, sentimentos e desejos compatíveis com as dinâmicas e necessidades momentâneas apresentadas por milhares de pessoas reunidas para festejar?

Bondía (2002) considera os sujeitos contemporâneos como seres agitados e em constante estado de excitação. E, segundo entende, essa ebulição e alteração incessantes os estimulam a manterem-se em constante movimentação no tocante às suas rotinas laborativas e nas suas escolhas de convívio social. Lugares onde experiências memoráveis podem ser vividas e significadas existem a partir do compartilhamento de experiências intersubjetivas entre seres humanos que os qualificam como tal. Nesse sentido, é imperativo recordar o entendimento de Bondía (2002) acerca da necessária redução do ritmo, da velocidade e dos deslocamentos, almejando permitir que a intensidade dos fluxos incessantes da vida contemporânea recue de modo a possibilitar experiências e o notar das experiências para os sujeitos. O pensamento de Bondía (2002) ecoa o de Tuan (2013, p. 224) quando este afirma que "o homem moderno se movimenta tanto, que não tem tempo para criar raízes; sua experiência e apreciação de lugar é superficial". Compartilhar coisas e fenômenos para os quais os indivíduos se voltam coletivamente requer, em algum momento, a pausa como condição de experimentação e organização do que está acontecendo para fruição e satisfação individual.

Viver e pesquisar festivais permite atentar para ampliações das escalas temporais e espaciais nas quais esses eventos são usualmente considerados. Isto é, identificar fluxos fortemente vinculados aos festivais ainda que, nem por isso, limitados a eles. Os festivais que podem ser vividos e interpretados como pausa extraordinária nos movimentos do cotidiano podem, muitas vezes, demandar a necessidade do acréscimo de outras pausas antes do retorno à cotidianidade. Em complemento a essas reflexões abre-se 
a oportunidade de pensar como o turismo, integrado e compreensivo a essas dinâmicas, pode servir ao propósito de oferecer aos sujeitos as experiências que desejam viver. Ou, então, facilitar os caminhos em direção ao destino escolhido como meta e realização.

O Tomorrowland é considerado um megafestival internacional de música eletrônica. A divisão cronológica de suas atrações e serviços incorpora a dimensão temporal no sentido de oferecer, entre as muitas horas de experiências musicais, visuais, olfativas e gastronômicas, o acampamento, as áreas de repouso (chil out) e ambientes reservados à contemplação da natureza e à redução das intensas atividades cerebrais e motoras. Essa pausa se apresenta como elemento fundamental para os participantes recuperarem o fôlego, descansarem corpos e sentidos antes de os submeterem por ininterruptas horas de bombardeios multissensoriais e, também, como oportunidades para o processamento e significação das experiências festivas até então vividas.

A intencional valorização da dimensão temporal em megafestivais como o Tomorrowland ajusta-se à escala alcançada por festivais dessa natureza atualmente. $\mathrm{O}$ Tomorrowland abriga atualmente, palcos onde diversos gêneros e artistas da Electronic Dance Music (EDM) são apresentados. Desde as primeiras edições, oferece apresentações performáticas e se destaca pela monumentalidade do espaço destinado ao festival, acrescido pelo conjunto de elementos e aspectos de sua cenografia, decoração, gastronomia e produção em geral. No Brasil, os eventos aconteceram nos anos de 2015 e 2016, no Parque Maeda, em Itu, São Paulo. Em suas edições belgas, o festival ocorre, anualmente, no final do mês de julho, em Boom, uma pequena cidade nos arredores da Antuérpia.

Tamanha magnitude, monumentalidade e difusão midiática tornaram o Tomorrowland, ao longo de suas quinze edições, um dos maiores, melhores e mais desejados festivais de música eletrônica da contemporaneidade. Por conseguinte, as cidades escolhidas para receber e realizar os megaeventos se tornaram pontos resplandecentes capazes de despertar os desejos e atraírem os corpos de indivíduos integrantes de neotribos contemporâneas (MAFFESOLI, 2018) e de sociedades de fim de semana (St. JOHN, 2017) ancoradas na ideologia P.L.U.R., fortemente inspirada pelos ideais de paz, amor, união e respeito em busca de vivências e experimentações em um contexto de sociedade pós-moderna (MAFFESOLI, 2010; CHIAVERINI, 2009).

Sugerimos, que essas vivências coletivas entrecruzadas às experiências individuais, ambientadas em sociedades pós-modernas, oferecem renovados desafios para as atividades relacionadas com o turismo. E, inevitavelmente, aos estudos relativos ao tema.

\section{Notas sobre geografia e turismo no contexto da} era da experiência em sociedades de fim de

\section{semana}


A reunião e apresentação das ideias até agora expostas evidenciam possibilidades de (re)pensar o turismo, seus fluxos, atividades, agentes e ideias, assumindo e investindo na cultura como protagonista na tomada de consciência e influenciadora nas tomadas decisórias de indivíduos e grupos culturais no contexto da Era da Experiência em um mundo hiperconectado e de economia globalizada. Não se admite, atualmente, a possibilidade de pensar aproximações entre os campos da geografia e do turismo na atualidade à margem dos diálogos e interações interdisciplinares envolvendo o domínio de outras ciências e seus arcabouços teóricos, metodológicos e discursivos.

A provocação acima robustece o argumento pelo qual os enlaces entre turismo e geografia apresentam-se de modo complexo, diversificado, plural, multiescalar e multidimensional. Nas seções anteriores deste estudo foram apresentados elementos sobre modos de viver e festejar música eletrônica e como essas práticas, ocorrentes em determinados espaço e tempo, se oferecem como campo de possibilidades para novas abordagens sobre os sentidos, significados e oportunidades de valorização da experiência festiva direta ou indiretamente relacionada com as atividades turísticas.

Nesta seção, as possibilidades das conexões anteriormente apresentadas são contextualizadas a partir de importantes mudanças ocorridas no campo das ciências sociais e das humanidades em geral. Até o início da segunda metade do século passado, os estudos científicos no campo das humanidades em geral, e da geografia em particular, se orientavam pelos caminhos do positivismo. Abordagens mais críticas, vinculadas ao materialismo histórico e dialético, começavam a disputar protagonismo na eleição de temas, agendas de pesquisas, formulações teóricas e proposições metodológicas para as pesquisas em curso. Inevitavelmente, investigações científicas foram executadas procurando identificar e analisar conflitos, tensões e contradições entre os diferentes agentes e atores espaciais. Assim como aqueles indivíduos, grupos, entidades e instituições empenhadas em transformar a natureza do espaço geográfico, suas paisagens, as atividades econômicas que comportam e o valor de seus usos material e simbólico.

Contudo, ainda assim, questões mais subjetivas em relação aos modos como os indivíduos significam suas experiências espaciais nas múltiplas temporalidades (extra)ordinárias da vida não encontravam campo para florescer. Lindón e Hiernaux (2010) descortinam um panorama complexo de rupturas, permanências, continuidades e atravessamentos pelos quais a geografia, enquanto ciência social abarcada pelas humanidades, vem sendo submetida. Guinadas espaciais, geográficas e culturais, endereçam novos rumos - e destinos - para pesquisas fundamentadas nas múltiplas possibilidades de abordar os fenômenos espaciais, dentre os quais, os que envolvem mobilidades de indivíduos e grupos.

O turismo, enquanto invenção e prática humana, realizado a partir dos desejos e realizações individuais e coletivas no espaço geográfico, não se furta a ser incorporado por essas novas maneiras 
de ver, sentir e estudar as espacialidades das formas, construções e atividades humanas. Na aurora da década de 1970, emprenhadas pela (contra)cultura hippie e seu vasto repertório imagético, estético, performativo e artístico, trilhas de uma Nova Geografia Cultural começaram a ser desbravadas. Por elas, estudos geográficos enfocando os significados de construções e ações humanas no espaço são (re)pensados e (re)examinados a partir do contexto de suas criações e do modo como vinham sendo vividos e significados.

Interpretações simbólicas de indivíduos e dos grupos culturais sobre determinadas parcelas do espaço geográfico, lugares e paisagens passaram a receber atenção especial de pesquisadores interessados em conhecer os diferentes modos de significar ações humanas espacializadas. Essas abordagens culturais do espaço apresentam possibilidades renovadas para tratar de temas como o turismo. Valorizar o turismo e o conjunto de suas formulações e realizações materiais, simbólicas, teóricas e os fluxos que as atravessam se torna rico manancial de elementos a serem investigados. Nos termos das ideias aqui ventiladas, as aproximações entre o campo geográfico e o turismo evidenciam este setor como dispositivo das culturas em que é desenvolvido. O turismo, portanto, inscreve-se e depende das dimensões espaciais e temporais dos espaços e lugares por onde se desenvolve. Contudo, a atividade turística também age no sentido de transformar os espaços e lugares onde ocorre. E são os seus atores e agentes, direta e/ou indiretamente envolvidos com as dinâmicas do turismo, que atuam como agentes modeladores do espaço geográfico (ROSENDAHL, 2011).

As mobilidades oportunizadas pelo turismo, no âmbito das novas abordagens humanistas culturais oportunizadas pelo giro cultural, se apresentam como potentes - e ainda pouco explorados temas de estudos na atualidade. Nesse sentido,

peregrinaciones, fiestas, celebraciones religiosas, circuitos sagrados, turismo religioso, viajes espirituales, entre otros fenómenos, emergen como múltiples expresiones de los flujos e itinerarios que hacen a lo territorial. En todos ellos, el componente espacial (la espacialidad) no es una variable menor; muy por el contrario, tiene una trascendencia central para pensar cómo funcionan, se construyen y se reproducen estos dispositivos" (CARBALLO, FLORES, 2016, p. 20)

As oportunidades de investir em abordagens humanistas culturais enfocando enlaces entre festas, festivais e modos de festejar com atividades turísticas se afastam do conjunto de estudos que, tradicionalmente, se ocupam em distinguir ravers de festivaleiros, estes de turistas, turistas de visitantes e as possibilidades de aproximação e/ou afastamentos relativas a esses exercícios de categorização das identidades dos sujeitos em deslocamentos pelo espaço. Nesses casos o espaço geográfico, muitas vezes, é relegado à condição de suporte físico e material onde e quando as práticas festivas e turísticas ocorrem. E as festas e o turismo como 
construções e dinâmicas humanas orientadas para o consumo e para o entretenimento e lazer.

Abordagens humanistas culturais, como nos dedicamos a apresentá-las neste ensaio, se aproximam da valorização dos sentidos e significados construídos em relação à experiência dos sujeitos que festejam e se movem pelo espaço geográfico em busca da satisfação de seus desejos. Há, portanto, maior atenção às subjetividades emergentes quando os indivíduos escolhem se lançar no mundo para viver experiências memoráveis, admitindo alternâncias nos modos como são valorizadas, no decurso dos fluxos nos quais essas pausas e movimentos se inscrevem.

Complementarmente, é possível sugerir mobilidades festivas e aproximações com o turismo como uma ideia a ser trabalhada em pesquisas futuras. Restringir pesquisas, estudos e atividades aos domínios da festa ou do turismo, de maneira estanque e segmentada, não condiz com as estratégias de viabilizar experiências festivas e turísticas atualmente. Tampouco se coadunam com a Era da Experiência de um mundo cada vez mais integrado e vivido por intermédio do compartilhamento de imagens, sonoridades, músicas, relatos, narrativas e de análises pessoais das experiências vividas e significadas como memoráveis. Contemporaneamente, empresas e as pessoas que atuam como construtoras de marcas e promotoras de experiências corporativas investem no oferecimento de oportunidades para eventos capazes de promover transformações pessoais.
De acordo com Gorgone (2017), viagens podem ensejar transformações nas subjetividades de pessoas. Flores e Oviedo (2017) sinalizam que o turismo também está sendo transformado, orientado para um consumo destinado a práticas e experiências de natureza espiritual. Os autores corroboram seu argumento discorrendo acerca do turismo xamânico e neo-xamânico e do turismo New Age. Nas trilhas dessas contribuições, novas sendas se abrem. E incorporam possibilidades alternativas de se estudar, por intermédio das festas e modos de festejar, experiências turísticas relacionadas com turismo esotérico, turismo místico, ufoturismo, ecoturismo em ecovilas e/ou modalidades mais diretamente conectadas com o turismo de eventos festivos como raves e festivais transformacionais

Resgatando a metáfora dos giros é possível anunciar uma guinada de estudos que investem nas aproximações entre geografia e turismo em função das análises morfológicas, isto é, atinentes às formas e estruturas em determinada localização (em termos de suas permanências) para as interpretações simbólicas enfatizando sentidos e significados expressos por ações humanas no espaço (em termos de suas emergências). Convém atentar para outro rodopio, talvez não tão evidente à primeira vista, na dimensão temporal dessas mudanças. Ao apontar emergências em detrimento a permanências, investe-se na volatilidade e transitoriedade das experiências festivas e turísticas. E, inevitavelmente, abarca-se quem festeja e quem dinamiza o turismo. Os indivíduos contemporâneos, 
organizados em comunidades psíquicas, neotribos ou sociedades de fim de semana são os sujeitos do tempo presente que, ao modificar os modos como atuam e valorizam suas ações no espaço geográfico, desafiam novas maneiras de pesquisar - e significar - os sentidos dessas transformações.

Aproximações que associam turismo e festivais de música no Brasil vêm sendo buscadas por inúmeros pesquisadores nas últimas décadas. Entretanto, no que tange aos estudos sobre entrelaçamentos de festivais de música eletrônica, geografia e turismo, afunilam-se o quantitativo de esforços investigativos empreendidos nesse campo Ainda assim, percorrendo e desbravando as veredas resultantes do encontro entre festivais de música eletrônica e turismo, Bosso e Carvalho (2016) destacam possibilidades de examinar impactos positivos e negativos relacionados à realização de um megafestival Para as pioneiras autoras, o estudo de caso fundamentado na edição do Tomorrowland Brasil 2015 apresenta-se como marco e objeto de reflexão sobre como grandes eventos, examinados pela ótica de estudos conectados ao turismo, podem ser analisados em termos econômicos, sociais, culturais, político-administrativos e ambientais.

No campo dos estudos geográficos de manifestações da cultura, a concretude da experiência espacializada envolve, concomitantemente, operações objetivas e relações intersubjetivas entre organizadores, patrocinadores, poder público, produtores culturais, mídia especializada, marcas e participantes em geral nos espaços e temporalidades festivas. O lugar, enquanto conceito-chave da geografia, é tido como elemento central e caro ao entendimento de perspectivas capazes de permitir interligações entre a experiência vivida ao festejar em articulação com sua condição de ponto nodal em redes receptoras e emissoras de fluxos variados no âmbito de relações entre as escalas local e global (MASSEY, 2000).

Tanto no Brasil quanto na Bélgica, a festa se ativa em um momento e em um lugar específicos. Na escala do indivíduo, é possível que a festa se amplie conforme os participantes a valorizem enquanto experiência relevante, luminosa e memorável em sua vida $\mathrm{Na}$ rede de fixos e fluxos, o lugar da festa integra e participa ativamente, ainda que de maneira diferenciada, das dinâmicas ocorrentes nas escalas local e global. Os eventos geográficos festivos (SILVA, 2013) realizados em Boom e Itu oferecem aos participantes um conjunto de atrativos físicos e simbólicos, os quais são identificados e apresentados pelos organizadores do evento, e percebidos e significados pelos participantes como condicionantes da experiência festiva e de atividades turísticas direta e indiretamente a ela associadas.

No caso em tela, paisagens ruralizadas são escolhidas, anunciadas e recebidas em contraste com o cotidiano urbano da imensa maioria dos frequentadores de megafestivais de música eletrônica. Possibilidades de rompimento com o cotidiano, inclusive em relação a paisagens e rotinas associadas ao ordinário fluxo da vida citadina, se apresentam em consonância com o ato de projetar aventuras - escapistas - a serem vividas em realidades alternativas. 
Segundo Cosgrove (2012, p. 223-224) conjunções entre cultura e simbolismo, presentes nas paisagens humanas, portanto culturais,

abordam os laços entre vida humana, amor e sentimento e os ritmos invariáveis do mundo natural: a passagem das estações, o ciclo de nascimento, crescimento, reprodução, envelhecimento, morte, deterioração renascimento, e o reflexo imaginado dos sentimentos e emoções humanas no aspecto das formas naturais

A aventura de escapar para outras realidades (TUAN, 2015) projetando em outros espaços e temporalidades identidades e/ou modos alternativos de ver e viver o mundo, é potencializada quando valores, emoções e ideias são impregnadas nas paisagens culturais (COSGROVE, 2012) e encarnados nos lugares simbólicos. Desse modo, possibilitam a instauração do tempo e lugar da festa na dimensão do extraordinário, do sobrenatural e, algumas vezes, do mágico ou (quase) religioso. Especialmente no contexto de sociedades civis, seculares, laicizadas e laicizantes, comumente reconhecidas no mundo contemporâneo (CLAVAL, 2010; ROSENDAHL, 2011; NOVO, 2014, 2019).

Os impactos, positivos e negativos, oportunizados pelos festivais, alinham-se com a escala dos referidos eventos assim como da própria localidade que sedia o evento. A magnitude do festival, seja em termos econômicos ou culturais, integra-se ao conjunto de elementos, atrações e características que a cidade e o país oferecem aos participantes egressos de diferentes regiões ou nacionalidades. Os festivais, e as cidades onde se realizam, configuram-se em lugares atrativos para fluxos de pessoas desejosas por vivenciar experiências festivas no contexto de uma sociedade em que as relações sociais, de lazer e de entretenimento se organizam mediante a valorização e mercantilização dessas específicas atividades humanas (CORRÊA, 2018). Constatar essas dinâmicas auxilia na compreensão dos motivos pelos quais determinadas localidades buscam, muitas vezes disputando arduamente entre si, se tornarem sedes destes megaeventos. Seja nas escalas local, regional e, em alguns casos, nacional, os festivais reúnem fluxos dos mais variados tipos e intensidades para lugares específicos e em temporalidades determinadas (CORRÊA, 2018)

A convergência desses fluxos, no entanto, pode desencadear resultados positivos e/ou negativos. A valoração vai depender daquilo que se afere, da metodologia utilizada ou do viés que se utilize para tal feito. No contexto espacial e temporal da realização de festivais, abordagens com vieses mais direcionados para questões políticas e econômicas oferecem, como resultados gerais, constatações de que os participantes se deslocam pelo espaço geográfico para consumir bens e serviços no local e na região Segundo Tosun (2002), estudos enfocando impactos causados por festivais apontam, recorrentemente, para alguns resultados usualmente tidos como negativos. Dentre os quais: 
i. o aumento dos preços dos bens e serviços durante os eventos;

ii. o congestionamento de trânsito nos locais

iii. problemas referentes ao parqueamento.

Seguindo por essa perspectiva, entendemos que os fluxos atribuídos ao turismo podem, em alguns casos, depredar algumas das instalações e equipamentos de uso coletivo do município, impactando a cultura autóctone e, frequentemente, constituindo-se em vetores de transformação acelerada dos valores de uso e ocupação do solo em áreas rurais e urbanas, especialmente a partir dos processos de especulação do solo e da paisagem (SARMENTO, 2007).

Ainda sob abordagens mais voltadas à dimensão mercantil, as principais vantagens para a realização de eventos de grande porte como o Tomorrowland ou Boom, seja no Brasil, na Bélgica ou em Portugal, evidenciam aspectos relacionados aos domínios da própria economia assim como da cultura e da oferta de benefícios para a sociedade (SARMENTO, 2007). Em termos econômicos, a realização desses megaeventos mobiliza expressivos quantitativos de visitantes e turistas deslocando-se interregionalmente. Por vezes, como nos casos em tela, a mobilidade ocorre em fluxos na escala internacional. É importante, nesse caso, destacar a escala de abrangência espacial do fenômeno assim como o poder de comunicar e atrair em função de sua constituição enquanto forma simbólica espacial (CORRÊA, 2018) concebida, materializada, consumida como experiência de luxo (LIPOVETSKY, 1998) e significada no âmbito da atual fase do capitalismo contemporâneo.

Participantes, ao empreender deslocamentos entre diferentes regiões e países, são atraídos para lugares específicos. E impactam, consideravelmente, o terceiro setor da economia local (SARMENTO, 2007). Não obstante, inovações relativas ao ato de pousar no lugar, por intermédio de plataformas e aplicativos como o AirBnB, permitem novas dinâmicas sociais especializadas para os grupos de ravers e/ou festivaleiros. Muitos participantes dos festivais, uma vez presentes na Europa ou no Brasil para o evento, aproveitam para conhecer outros estados e/ou países vizinhos. Algumas empresas, patrocinadoras destes megaeventos, buscam criar/atrair/potencializar esses fluxos.

Uma das estratégias amplamente divulgada possui, como objetivo principal, conferir maior visibilidade para as marcas parceiras por meio de ações de marketing especialmente planejadas e executadas para esses grandes eventos (SOARES, 2014). Nesses casos os festivais, constituindo-se primeiramente como fixos, se tornam hubs para pesquisa, desenvolvimento e lançamento de ações, produtos e serviços, assim como lugares de inovação no contexto da Era da Experiência contemporânea (PINE \& GILMORE, 1998). Cabe, nesse momento, o questionamento: e por que não podem oferecer ainda mais dados e informações qualificados aos estudos direta e indiretamente relacionados com as atividades turísticas? 
Hubs são espaços projetados e criados para promover trocas variadas entre diferentes atores no âmbito de um ou mais segmentos/setores como, por exemplo: tecnologia, marketing, inovação, esportes, entretenimento, entre outros. No contexto da Era da Experiência, a difusão da língua inglesa precisa ser entendida como mais um agente da globalização no âmbito de momentos de lazer, entretenimento e fruição oportunizados pela compra de ingressos para festejar música eletrônica e de modo a participar, de modos mais ou menos diretos, das atividades turísticas já existentes na região.

Segundo Sarmento (2007), existem aspectos culturais a serem evidenciados e compreendidos a partir das dinâmicas de grandes festivais. Festivais apresentando características dessa natureza propiciam, em geral, novas experiências, oportunizando contatos com (sujeitos de) outras culturas e, ainda, se oferecendo como lugar e tempo para manifestações diversificadas de atividades artísticas e musicais. Ainda, de acordo com o autor, festivais se encarregam por um aspecto considerado benéfico ao quadro social local: dinamizar interações positivas entre turistas e visitantes.

Festivais tradicionais, como os já citados Boom e Tomorrowland, contribuem para desenvolver diferentes campos ou setores, os quais objetivam melhorar o bem-estar de turistas, de visitantes e da população em geral; em especial daquela parcela cotidianamente usuária dos serviços disponíveis na localidade e impactada direta e indiretamente pela realização dos megaeventos.
No caso do Tomorrowland, especialmente em sua localidade de origem, Boom, na Bélgica, a organização do festival possui estratégias de manutenção, com a comunidade local, de uma política de aproximação e boa vizinhança. Assumindo-se como causadora de impactos negativos na localidade, especialmente durante a ocorrência do festival, a organização procura estreitar os laços com a população local quando o festival não está acontecendo e, também, durante sua realização.

$\mathrm{O}$ estreitamente das relações entre as partes diretamente em contato por ocasião dos eventos festivos não pode ser entendida sem que se considere a existência de tensionamentos, conflitos e territorialidades. Não obstante, a existência de um festiva mundialmente conhecido ilumina a bucólica Boom como ponto cintilante na rede de lugares cerzidos nas tramas que reúnem trajetórias espaciais de visitantes de todo o mundo. Ao chegarem a Boom, essas pessoas entram em contato com a comunidade e o lugar que hospeda o festival desde a sua primeira edição. Muitos participantes, enquanto se deslocam pelas ruas de Boom, carregam celulares e câmeras fotográficas. Artefatos que vão sendo disparados conforme se deslocam entre pausas e movimentos, reconfigurando, enquanto agem no espaço, o balé do lugar cotidiano da cidade (SEAMON, 2011). Ao serem questionados acerca daquilo que buscavam registrar na área exterior à do evento, as respostas, em resumo, expressavam o imenso prazer e realização de estarem ali, naquele lugar onde tudo começou. 
A resposta acima, repetida por sujeitos festivaleiros de diversas nacionalidades, aponta para a possibilidade de entender Boom, de maneira mais geral, e o lugar especialmente dedicado para abrigar o festival, em especial, por uma perspectiva capaz de identificar e valorizar o espírito do lugar. Segundo Edward Relph (2012), lugares podem ser tão especiais para determinados indivíduos ou grupos que estes passam a construir histórias e narrativas fantásticas para torná-los ainda mais singulares. Uma das estratégias, recorrente no decorrer da história, é a criação de narrações capazes de conferir a estes lugares predicativos extraordinários, muitas vezes remontando a tempos antigos, imemoriais, em que estas parcelas do espaço geográfico teriam sido escolhidas para serem diferentes das demais.

No caso do Tomorrowland, essa estratégia é replicada, e potencializada, pela organização do evento já que, a todo instante, empenha-se em reforçar as qualidades especiais, sobrenaturais e singulares da Terra do Amanhã. Nesse sentido, a ideia de que este lugar é especial e, por isso, ainda hoje é guardado por espíritos guardiões (RELPH, 2012) é continuamente evocada, participando de modo ativo nas histórias, narrativas, memórias e dinâmicas atuais e futuras dos participantes no lugar. Mas, como é possível identificar e/ou reconhecer esses lugares especiais? E como podem ser associadas e dinamizadas aos projetos relacionados ao turismo voltado para a perspectiva experiencial da festa?
Na complexidade inerente às interações do homem com o meio, uma relação de benquerência e afeição pode passar a existir. Desse relacionamento, singular, pessoal, intencional e subjetivo surge possibilidades de laços invisíveis guiarem o indivíduo, ou os grupos sociais, no mundo que imaginam e reconhecem fisicamente como seus quando seus corpos (re)conhecem aquilo que já foi previamente imaginado. Ao germinar essa relação topofílica, afinidades, sensações, emoções, sentimentos e memórias podem se vincular ao lugar. Com isso, valores presentes nas experiências da vida cotidiana passam a possuir significados ensejadores de pertencimentos do ser humano com o espaço geográfico especialmente qualificado pelas experiências. Essa interação entre os homens e o meio é plena de idas e vindas. E cabe aos seres humanos autonomia para escolher quando e onde desejam vivê-las. Nesse entendimento, o lugar constitui-se como centro de ação e intenção e, desse modo, ele se torna o lócus onde nós experienciamos eventos significativos da nossa experiência (RELPH, 2012).

A mesma linha de raciocínio está presente quando o termo espírito de lugar é associado a lugares excepcionais (RELPH, 2012). Lugares, vividos e entendidos desse modo, possuem a capacidade de organizar significados em determinados contextos, impregnando certos ambientes de sentido conforme vão sendo transformados pelas experiências de indivíduos e pelas vivências de determinados grupos sociais. Entende-se que o lugar, por essa perspectiva, possui um genius, uma espécie de espírito guardião. Esse espírito confere vida 
às pessoas e aos lugares, acompanhando-os do nascimento à morte, influenciando seu caráter, suas escolhas e as dinâmicas espaciais de seu cotidiano e da vida em geral (RELPH, 2012).

A possibilidade de supor um genius loci requer elaborado conjunto de signos, historietas e estratégias engendradas por aqueles e aquelas que visam conferir ao lugar densidade histórica, simbólica e material. Nesse sentido, a história do festival está ancorada à memória da sociedade de fim de semana (ST. JOHN, 2014; 2017) que o elege como ponto central de uma malha complexa de lugares para festejar música eletrônica. Esse lugar edifica-se quando essa memória é evocada, reificada, revivida por palavras, atitudes, imagens e vivências, quer seja nos lugares e temporalidades festivos, quer seja nos demais espaço e tempo nos quais o festival é (re)construído a partir da negociação de seus sentidos e significados no âmbito da cultura popular (STOREY, 2012) e pelos inúmeros atores que participam desse incessante processo (FERREIRA, 2002 2005).

\section{Considerações finais}

O conjunto dos pensamentos aqui expostos apresenta possibilidades de novos enlaces entre fenômenos e práticas vinculadas aos diferentes modos de festejar música eletrônica na contemporaneidade com atividades relacionadas com o turismo na aurora do século XXI. Essas aproximações sugerem horizontes sedutores para a invenção de novas práticas e um campo frutífero para novas abordagens científicas a esse respeito. As confluências possíveis refletem buscas empreendidas por integrantes de sociedades de fim de semana que festejam como prática existencial e significativa de suas vidas e como ações capazes de superar distâncias no espaço, qualificando-o em lugar onde essas realizações são dotadas de sentidos e significados.

Nesse contexto, a prática de festejar música eletrônica associada com atividades turísticas envolve, cada vez mais, a procura, a elaboração, o consumo e a consumação de experiências heterodoxas e liminares. Desse modo, conceitos e ideias de estudos e pesquisadores das áreas de geografia e turismo precisam ser alargados, na medida em que a complexidade dos modos de praticar turismo e festejar música eletrônica se verifica cada vez mais presente - e significativo - na vida dos grupos que as consideram relevantes. Não menos importante, também se tornam economicamente mais relevantes para grupos, setores e até mesmo cidades direta e indiretamente envolvidos com essas ações.

Clubes noturnos, eventos ao ar livre como paradas de rua e grandes festivais de música eletrônica apresentam-se nas linhas aqui ensaiadas como fatos sociais totais. E, desse modo, também são vividos e significados como fatos das culturas em ação e difusão na contemporaneidade. Entendidos como expressão dos valores, hábitos e costumes de indivíduos e de grupos culturais, ou analisados como integrantes da cadeia produtiva da economia criativa e cultural, 
clubes, eventos ao ar livre e megafestivais de música oportunizam discussões acerca de como são acessados e vividos pelo conjunto de seus participantes. No âmbito da Era da Experiência, esses eventos geográficos festivos almejam (re)produzir um evento experiencial. E o fazem não como apoio ou motivados por causas externas aos eventos que são e realizam. E sim como laboratórios do presente, tornando-se a razão de ser-e-estar no mundo dos membros da comunidade festejante. Estar em um festival e viver a experiência de um festival pode se tornar - ou revelar - escolhas existenciais, colaborando para a descoberta e/ou confirmação do sentido de serno-mundo para milhares de indivíduos naturais das mais diversas localidades.

As atividades turísticas, arejadas e abaladas por sucessivas mudanças comportamentais e tecnológicas, podem e precisam se adaptar de maneira a acolher e participar da organização, promoção e significação das experiências festivas de sujeitos dispostos a viver momentos memoráveis em lugares especialmente projetados para o escapismo. A partir dos exemplos acionados para substanciar pensamentos, argumentos e discussões, esta proposta avança para a identificação de possibilidades de (novas) práticas e pesquisas que admitam abordagens culturais do espaço no âmbito da geografia humanista cultural e enlaces com dinâmicas turísticas e pesquisas no campo do turismo situadas em uma Era da Experiência no primeiro quartel do século XXI
As considerações finais apontam para a potência desses entrelaçamentos como campo fértil para investigações acadêmicas e a oferta qualitativa de experiências cada vez mais adequadas com as expectativas de sujeitos interessados em viver alguns dos melhores momentos de suas vidas no curso de múltiplas temporalidades associadas ao festejar música eletrônica. Finalmente, é importante salientar que impactos decorrentes da realização das dinâmicas festivas aqui apresentadas devem ser problematizados e entendidos como potenciais riscos para grupos compostos por sujeitos com distintas visões de mundo e manifestando diferentes motivações e desejos. Há extenso corolário de ações responsáveis por negativar a percepção de valor relativa ao festejar nos termos aqui expostos. Essas tensões existem e devem ser incorporadas nas análises, críticas e na formulação de caminhos alternativos para estudos e atos individuais e coletivos no espaço geográfico ordinário da vida cotidiana ou naquele inventado e vivido como radiante e extraordinária experiência festiva por turistas, festivaleiros e/ou interessados pelas festas e pelo que elas permitem transformar

\section{Referências}

BONDÍA, Jorge Larossa. Notas sobre a experiência e o saber de experiência. Barcelona: Universidade de Barcelona, 2002.

BOSSO, Julia Nicolosi; CARVALHO, Alissandra Nazarethi Tomorrowland Brasil e Itu/SP: um estudo de caso sobre a relação 
entre um grande evento e um pequeno município. Revista Iberoamericana de Turismo - RITUR, v. 6, n.2, 2016, p. 92-117.

CARBALLO, Cristina. y FLORES, Fábian. Territorios, fiestas paisajes peregrinos: cartografías sociales de lo sagrado en el siglo XXI. Buenos Aires: Imprenta Editorial, 2016.

CAVALCANTI, Maria Laura Viveiros de Castro. O rito e o tempo: ensaios sobre o carnaval. Rio de Janeiro: Civilização Brasileira, 1999.

CHIAVERINI, Tomás. Festa infinita: o entorpecente mundo da raves. São Paulo: Ediouro, 2009.

CLAVAL, Paul. O tema da religião nos estudos geográficos. Espaço e cultura, n. 7, 1999, p. 37-58

CLAVAL, Paul. Terra dos homens: a geografia. Tradução de Domitila Madureira. São Paulo: Contexto, 2010.

CORRÊA, Roberto Lobato; ROSENDAHL, Zeny. Literatura, Música e espaço: uma introdução. In: CORRÊA, Roberto Lobato; ROSENDAHL, Zeny (Orgs.). Literatura, música e espaço. Rio de Janeiro: EDUERJ, 2007, p. 7-8

CORRÊA, Roberto Lobato; ROSENDAHL, Zeny (Orgs.). Caminhos paralelos e entrecruzados. São Paulo: Editora Unesp, 2018.

COSGROVE, Denis. Mundos de Significados: geografia e Imaginação. In: CORRÊA, Roberto Lobato; ROSENDAHL, Zeny (Orgs.). Geografia cultural: um século (2). Rio de Janeiro: EDUERJ, 2000.

COSGROVE, Denis. A geografia está em toda a parte: cultura e simbolismo nas paisagens humanas. In: CORRÊA, Roberto Lobato; ROSENDAHL, Zeny (Orgs.). Geografia cultural: uma antologia Rio de Janeiro: EDUERJ, 2012, p. 219-238.
DJ MAG BRASIL. Techno é considerado patrimônio cultural intangivel. http://dimagbr.com/techno-e-considerado-patrimoniocultural-intangivel/. (Disponível em: 12/07/2017). Acesso em 09/08/2020.

DUVIGNAUD, Jean. Festas e civilizações. Fortaleza: UFCE; Rio de Janeiro: Tempo Brasileiro, 1977.

FERREIRA, Felipe. O lugar do carnaval: espaço e poder na festa carnavalesca do Rio de Janeiro, Paris e Nice (1850-1930). Tese (Doutorado em Geografia) - Programa de Pós-Graduação em Geografia, Universidade Federal do Rio de Janeiro, Rio de Janeiro, 2002.

FERREIRA, Felipe. Inventando carnavais: o surgimento do carnaval carioca no século XIX e outras questões carnavalescas. Rio de Janeiro: Editora da UFRJ, 2005.

FLORES, Fábian; OVIEDO, Maximiliano Elias. Imaginarios turísticos, construcción de atractivos y New Age: el caso de San Marcos Sierras (Argentina). Revista Estudios y Perspectivas en Turismo, v. 26, n. 2, 2017, p. 493-508

FLORES, Fábian; CÁCERES, Carlos Roberto. Lecturas culturales del fenómeno turístico: experiencias sobre los turismos religiosos. Revista Posición, v. 1, n. 1, 2019, p. 1-24.

GORGONE PAMPIN, Aluminé. Nomadismo turístico en la Patagonia: prácticas, espacios y reflexividades en un marco intersubjetivo. II Coloquio latinoamericano: Territorios, Fiestas y Paisajes Peregrinos. Luján-Quilmes, 2017.

HAESBAERT, Rogério. Reflexões geográficas em tempos de pandemia. Espaço e Economia: Revista Brasileira de Geografia Econômica, 2020, p. 1-5 
LIPOVETSKY, Gilles; ROUX, Elyette. O luxo eterno: da idade do sagrado ao tempo das marcas. São Paulo: Companhia das Letras, 1998

LINDÓN, Alícia; HIERNAUX, Daniel. Los giros de la geografía humana: desafíos y horizontes. Ciudad de Mexico: Antrophos, 2010.

LOWENTHAL, David. Geografia, experiência e imaginação: em direção a uma epistemologia geográfica. In: CHRISTOFOLETTI Antonio (org.). Perspectivas da Geografia. São Paulo: Difel, 1982.

MAIA, Carlos Eduardo Santos. Soltando o verbo: ratos e urubus, diretamente o povo escolhia o presidente. Textos Escolhidos de Cultura e Arte Populares. v. 7, n. 2, 2010, p. 109-125.

MAFFESOLI, Michel. O tempo das tribos: o declínio do individualismo nas sociedades de massa. Rio de Janeiro: Forense Universitária, 2010.

MASSEY, Doreen. Um sentido global do lugar. In: ARANTES, Antônio (Org.). O espaço da diferença. Campinas: Papirus, 2000, p 176-185,

NOVO, Cássio Lopes da Cruz. A concentração de blocos carnavalescos: espaços pseudo sagrados na folia momesca. In Congresso Internacional de Núcleo de Estudos das Américas. Rio de Janeiro: Nucleas, 2014

NOVO, Cássio Lopes da Cruz. Tomorrowland: imaginações geográficas, corporeidade e a perspectiva experiencial do luga festivo. Tese (Doutorado em geografia) - Programa de PósGraduação em Geografia, Universidade do Estado do Rio de Janeiro, Rio de Janeiro, 2019.

PINE, Joseph e GILMORE, James. Welcome to the experience economy. Harvard Business Review, n. july-august, 1998.

RELPH, Edward. Reflexões sobre a emergência, aspectos e essência do lugar. In: MARANDOLA JR., Eduardo; HOLZER, Werther OLIVEIRA, Lívia de. (Orgs.). Qual o espaço do lugar?: geografia, epistemologia, fenomenologia. São Paulo: Ed. Perspectiva, 2012, p. $17-32$.

REYNOLDS, Simon. Generation ecstasy: into the world of techno and rave culture. Nova York: Routledge, 1999.

ROSENDAHL, Zeny. Espaço, cultura e religião: dimensões de análise. In: CORRÊA, Roberto Lobato; ROSENDAHL, Zeny. Introdução à geografia cultural. $5^{\mathrm{a}}$ ed. Rio de Janeiro: Bertrand Brasil, 2011, p. 187-224.

ROSENDAHL, Zeny. Tempo e temporalidade, espaço e espacialidade: a temporalização do espaço sagrado. Espaço $e$ Cultura, n. 35, 2014, p. 9-35.

SANTOS, Milton. O Espaço do Cidadão. São Paulo: Ed. Nobel, 1987.

SARMENTO, João. Festivais de música de verão: artes performativas, turismo e território. Guimarães: Universidade do Minho - Instituto de Ciências Sociais - Núcleo de Investigação em Geografia e Planejamento, 2007. (Geo-Working Papers: Série Investigação 2007/13)

SEAMON, David. A geography of the lifeworld. New York: St Martin's, 2011.

SILVA, Anelino Francisco da. Festas Geográficas: de carnavais a eventos juninos e populares. Natal: EDUFRN, 2013.

SOARES, Maria Carolina. A festa não tem fim: experiências compartilhadas por fãs de música eletrônica no Facebook e en festivais. Dissertação (Mestrado em Antropologia) - Programa de Pós-Graduação em Antropologia, Universidade Federal Fluminense, Niterói, 2014.

St. JOHN, Graham. Liminal culture and global movement: the transitional world of psytrance. In: St. JOHN, Graham (Ed.) The local Scenes and global culture of psytrance. New York: Routledge, 2010, p. 220-246. 
St. JOHN, Graham. Goatrance Travellers: Psychedelic Trance and its Seasoned Progeny. In: Krüger, Simone; Trandafoiu, Ruxandra (Eds.) The globalization of musics in transit: musical migration and tourism. New York: Routledge, 2014, p 160-182.

St. JOHN, Graham.Weekend societies: electronic dance music festivals and event-cultures. New York: Bloomsbury Publishing, 2017

STOREY, John. Teoria cultural e cultura popular: uma introdução. São Paulo: Editora Sesc, 2015.

TOSUN, Cevat. Host perceptions of impacts: a comparative tourism study. Annals of Tourism, v. 29, n. 1, 2002, p. 231-253.

TUAN, Yi-Fu. Espaço e lugar: a perspectiva da experiência. Eduel Londrina, 2013.

TUAN, Yi-Fu. Geografía romántica: en busca del paisaje sublime. traducido del inglés por Borja Nogué; edición de Joan Nogué. Madrid: Biblioteca Nueva, 2015. 